\title{
The Role of Hepatitis B Core Antibody Testing in Improving Blood Safety in Resource-Limited Countries Study on Voluntary Blood Donors Fayoum, Egypt
}

Abeer Mohamed Abdelrazik ${ }^{\star}$ and Hossam M. Abdelaziz

Department of Clinical Pathology, Faculty of Medicine, DewanAam El Mohafza, Fayoum, Egypt

*Corresponding author: Abeer Mohamed Abdelrazik, Department of Clinical Pathology, Faculty of Medicine, DewanAam El Mohafza, Fayoum, Egypt, Tel: +9710561232602; E-mail: abdelrazik50@hotmail.com

Received date: Jul 09, 2015, Accepted date: July 17, 2015, Publication date: July 20, 2015

Copyright: (c) 2015 Abdelrazik AM, et al. This is an open-access article distributed under the terms of the Creative Commons Attribution License, which permits unrestricted use, distribution, and reproduction in any medium, provided the original author and source are credited.

\begin{abstract}
Background: Transmission of hepatitis B virus (HBV) via hepatitis B surface antigen (HBsAg) negative blood donors has been reported. HBsAg is still the only mandatory HBV screening test of blood donors in Egypt due to high cost of DNA testing of all collected blood. Many resource- limited countries have implemented screening antibodies to hepatitis B core antigen (anti-HBc) to further improve transfusion safety. The objective of study was to evaluate the significance of screening anti-HBc to reduce the risk of transfusion transmitted HBV infection in Egypt.
\end{abstract}

Study Design and Methods: The study was conducted on 800 voluntary blood donors negative for HBsAg, hepatitis $\mathrm{C}$ antibody (HCVAb) and human immunodeficiency virus Ab. They were subjected to screening for antiHBV core antibodies (total). Anti-HBc-positive samples were further tested for the antibodies to HBsAg (anti-HBs), and "anti-HBc alone" sera were tested for HBV DNA.

Results: Among 800 healthy voluntary donors, 99 (12.37\%) were anti-HBc-positive including 78 anti-HBs positive. The remaining 21 donors were anti-HBc alone, 2 of which (9.52\%) were HBV DNA-positive.

Conclusion: Greater consideration should be given to the implementation of anti-HBc as an additional screening test for blood donors in Egypt as the most cost-effective measure for further improvement of transfusion safety.

Keywords: Anti-HBc; Anti-HBc alone; Blood donors; Occult HBV infection

\section{Introduction}

Hepatitis B virus (HBV) remains a major public health problem. It is estimated that approximately 400 million people worldwide are chronically infected with HBV, where Egypt is considered as an area of intermediate endemicity [1]. Hepatitis B virus (HBV) is easily transmitted by blood products as both cellular and plasma-derived components may be infected [2].

Transfusion-transmitted HBV played a major role in the spread of this infection some decades ago all around the world, and is still a threat in developing countries, where the prevalence of this infection is higher and the donor selection and screening procedures are less tight $[2,3]$.

Occult hepatitis B infection (OBI) is defined by the presence of HBV DNA in the liver tissue of individuals who test negative for HBsAg, regardless of the detection of HBV DNA in serum [4]. OBI was reported for the first time almost 30 years ago in a case report of HBV infection through blood transfusion by an antibody to hepatitis $B$ core antigen (anti-HBc) only positive donor [5].

In most developed countries, nucleic acid amplification testing (NAT) has been introduced along with serological testing for HBV, hepatitis $\mathrm{C}$ virus and human immunodeficiency virus in order to enhance blood safety [6-8].
In contrast, limited-resources developing countries cannot implement NAT for screening of all donors collected blood and are relying on proper donor selection which is complemented by sensitive cost effective serological screening tests to exclude the transmission of infective agents $[9,10]$.

In Egypt, screening for HBsAg is the only mandatory screening test for the detection of Hepatitis B virus (HBV) infection in blood banks [1], only four qualified blood centres are already implementing NAT in Egypt, and these are National Cancer Institute (NCI) blood bank, blood bank of Nasser Institute, blood bank of EL-Shabrwishy Hospital (Private hospital) and the Egyptian Organization for biological products and vaccines (VACCERA) blood bank [11], given the constrained economy, lack of appropriate infrastructure and inadequate trained personnel that limit its implementation in all blood banks [12,13].

New cost-effective strategies and stringent donor selection implementation are very important measures to ensure blood safety in limited- resources countries.

The aim of this study was to determine the presence of $\mathrm{HBcAb}$ and HBV DNA among Fayoum university hospital blood bank HBsAg negative healthy blood donors to evaluate the significance of implementing screening anti-HBc to reduce the risk of transfusion transmitted HBV infection in Egypt blood banks. 


\section{Materials and Methods}

\section{Blood samples}

The present study included 800 samples from blood donors negative for anti- hepatitis $\mathrm{C}$ antibody (HCV), anti-human immunodeficiency virus (HIV), and HBsAg collected over a period of 6 months (from April 2014 to September 2014) in Fayoum university hospital blood bank.

\section{Detection of serologic markers}

Serum HBV total anti-HBc was performed by ELISA technique, Monoliza Anti-hepatitis B core Plus-Bio-Rad, according to manufacturer's instructions on all donor samples. Positive samples were subjected to quantitative detection of antibodies to hepatitis B surface (anti-HBs) with commercially available kits (ETI-AB-AUK-3, Dia Sorin-Italy). Serum anti-HBs titers $>10$ IU/L was considered positive.

\section{Detection of hepatitis B viral DNA}

HBV DNA level was estimated for blood units with low or undetectable serum anti-HBs levels "anti-HBc alone" using real time polymerase chain reaction (PCR) automated system. HBV fluorescence quantitative diagnostic kit (Hangzhou Bioer Technology, China). The kit combines the Viral DNA extraction and the technologies of nucleic acid amplification and hybridization probe. Real-time PCR was performed on the Chromo4 DNAEngine Peltier thermal Cycler (BIO-RAD, Hercules, CA). Thermal profile was set according to manufacturer's guideline.

\section{Statistical analysis}

Data were statistically described in terms of frequencies (number of cases) and percentages when appropriate. All statistical calculations were done using computer programs Microsoft Excel 2003 (Microsoft Corporation, NY, and USA) and SPSS (Statistical Package for the Social Science; SPSS Inc., Chicago, IL, USA) version 15 for Microsoft Windows.

\section{Results}

\section{Serological results}

All participants were negative for HBsAg. 99/800 (12.37\%) of blood donors were negative for $\mathrm{HBsAg}$ and positive for anti-HBc. Anti-HBs antibody was detected in 78/99 (78.78\%) of HBsAg negative and anti$\mathrm{HBc}$ positive samples, with serum levels $>10 \mathrm{IU} / \mathrm{L}$.

\section{Molecular findings}

Detection of HBV-DNA performed on all samples that were negative for HBsAg and positive for anti-HBc antibody only by use of real time PCR technique. HBV-DNA was detected in 2 out of 21 anti$\mathrm{HBc}$ positive specimens (9.52\%).

Results of antibodies to hepatitis B core, antibodies to hepatitis B surface and hepatitis $B$ virus DNA among the studied blood donors are summarized in Figure 1.

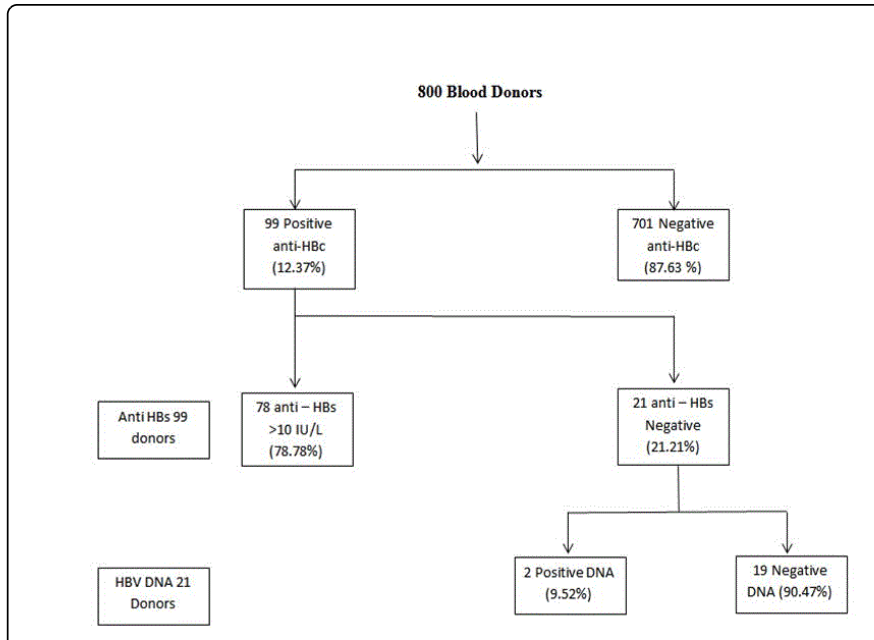

Figure 1: Results of antibodies to hepatitis B core, antibodies to hepatitis B surface and hepatitis B virus DNA among the studied blood donors.

\section{Discussion}

OBI is defined as the presence of HBV DNA in the liver (with detectable or undetectable HBV DNA in the serum) of individuals who tested negative for HBsAg [14,15]. Occult HBV is transmissible by blood transfusion, although the transmission rate is considered to be very low. The clinical outcome of OBI transmission mainly depends on the immune status and copies of HBV DNA in blood products of the recipient [16]. At present, $\mathrm{HBsAg}$ detection is the only obligatory diagnostic screening test for HBV infection in blood transfusion centers in Egypt $[12,13]$. We examined $800 \mathrm{HBsAg}$ negative sera obtained from healthy blood donors and found that $12.37 \%$ of them were positive for anti- $\mathrm{HBc}$, which is comparable to two previous Egyptian studies with a prevalence of $14.2 \%$ and $10.9 \%$ of $\mathrm{HBsAg}$ negative volunteer blood donors [1,17]. The study is also comparable to the older anti-HBc prevalence rates reported among HBsAgnegative blood donors in India; $10.01 \%$ [9] and $11.2 \%$ in Syria [10], respectively.

The prevalence of anti-HBc only in Europe and North America is overall quite low. A prevalence of $0.07 \%$ in the UK and $1.5 \%$ in Germany was reported $[18,19]$. In areas of higher HBV infection prevalence about $20 \%-70 \%$ of subjects are positive for anti-HBc antibody [20].

In our study the overall prevalence of occult HBV infection in healthy blood donors was $9.52 \%$ among anti-HBc positive alone individuals. Different results have been reported in other studies regarding the rate of $\mathrm{OBI}$ in blood donors. These differences in the occult HBV prevalence may be attributed to race and ethnicity, geographical area and the HBV subtypes [21,22]. The frequency of HBV-DNA detected in HBsAg negative samples also varies considerably according to the prevalence of the infection. In Northern countries where the prevalence of chronic infection is less than $1 \%$, no more than $5 \%$ of $\mathrm{HBsAg}$ negative/anti-HBc positive blood donor samples contain HBV-DNA $[19,23]$. In contrast, higher OBI levels in HBsAg-negative blood were recorded in several published reports. In India, the prevalence was $24 \%$ [24] and in a published study from 
Korea, $16 \%$ of the studied sample was found to be positive for OBI [25]. Other reports of the prevalence of HBV-DNA in only anti$\mathrm{HBc}$ positive blood donors revealed $0 \%$ in Brazil [26], 0.3\% in china [27], $1.1 \%$ in Japan [28], 3.2\% in Saudi Arabia [29] and $12.7 \%$ in Ghana [30]. Some information is available regarding the infectivity of anti-HBc-only blood products or organs. The infectivity of blood donations containing anti-HBc as the only marker of $\mathrm{HBV}$ infection has been known for several decades and indicated that no more than $4 \%$ of recipients of anti-HBc-only blood developed HBV infection post-transfusion [31]. However, Mosley reported $17 \%$ infectivity of antiHBc-only blood products [22,32]. Anti-HBc screening has the potential of excluding the vast majority of occult $\mathrm{HBV}$ infection but this exclusion of anti-HBc positive donors is impractical in countries where HBV infection is prevalent and higher than $20 \%$ of the populations are anti-HBc positive [33]. The use of HBV anti core testing to eliminate the residual transfusion risk of transmission of HBV has not been evaluated in Egypt.

\section{Conclusion}

One of the main mechanisms for OBI transmission is most likely through infected blood and its components and our findings revealed that OBI exists among Egyptian blood donors. Screening for HBsAg in blood banks in Egypt is not sufficient to completely exclude HBV infection in an intermediately endemic area like Egypt. NAT cannot be implemented for screening of all donors collected blood because of the high cost for a limited resources country like Egypt. New screening policy to further increase the safety of blood transfusion is strongly indicated.

Anti-HBc antibody should be tested routinely on blood donor volunteers, and if the sera become positive regardless of anti-HBs titer, the blood should be discarded. Further testing for HBV-DNA is appropriate to follow up the blood donor patient for HBV infection.

\section{Conflict of Interest}

There is no conflict of interest with any organization regarding the material discussed in the manuscript.

\section{References}

1. Said ZN, Sayed MH, Salama II, Aboel-Magd EK, Mahmoud MH, et al. (2013) Occult hepatitis B virus infection among Egyptian blood donors. World J Hepatol 5: 64-73.

2. Candotti D, Allain JP (2009) Transfusion-transmitted hepatitis B virus infection. J Hepatol 51: 798-809.

3. Romano L, Velati C, Cambie G, Fomiatti L, Galli C, et al. (2013) Hepatitis $\mathrm{B}$ virus infection among first-time blood donors in Italy: Prevalence and correlates between serological patterns and occult infection. Blood Transfus 11: 281-288.

4. Nishikawa H, Osaki Y (2013) Clinical significance of occult hepatitis B infection in progression of liver disease and carcinogenesis. J Cancer 4: 473-480.

5. Said ZN (2011) An overview of occult hepatitis B virus infection. World J Gastroenterol 17: 1927-1938.

6. De Mitri MS, Cassini R, Bernardi M (2010) Hepatitis B virus-related hepatocarcinogenesis: molecular oncogenic potential of clear or occult infections. Eur J Cancer 46: 2178-2186.

7. Nübling CM, Heiden M, Chudy M, Kress J, Seitz R, et al. (2009) Experience of mandatory nucleic acid test (NAT) screening across all blood organizations in Germany: NAT yield versus breakthrough transmissions. Transfusion 49: 1850-1858.
8. Allain JP, Candotti D (2009) Diagnostic algorithm for HBV safe transfusion. Blood Transfus 7: 174-182.

9. Ks M, R A, P A (2012) The prevalence of the hepatitis B core antibody and the occult hepatitis B infection among voluntary blood donors in chennai, India. J Clin Diagn Res 6: 1710-1712.

10. Muselmani W, Habbal W, Monem F (2013) Significance of screening antibodies to hepatitis B virus core antigen among Syrian blood donors. Transfus Med 23: 265-268.

11. Hans R, Marwaha N1 (2014) Nucleic acid testing-benefits and constraints. Asian J Transfus Sci 8: 2-3.

12. Omran D, Hussein EA, Nagib M (2013) Safety of Blood Transfusion: An Egyptian Study. J Infect Dis Ther 1: 124.

13. El-Zayadi AR, Ibrahim EH, Badran HM, Saeid A, Moneib NA, et al. (2008) Anti-HBc screening in Egyptian blood donors reduces the risk of hepatitis B virus transmission. Transfus Med 18: 55-61.

14. Baylis SA, Heath AB, Chudy M, Pisani G, Klotz A, et al. (2008) An international collaborative study to establish the 2nd World Health Organization International Standard for hepatitis B virus DNA nucleic acid amplification technology-based assays. Vox Sang 94: 358-362.

15. Raimondo G, Allain JP, Brunetto MR, Buendia MA, Chen DS, et al. (2008) Statements from the Taormina expert meeting on occult hepatitis B virus infection. J Hepatol 49: 652-657.

16. Satake M, Taira R, Yugi H, Hino S, Kanemitsu K, et al. (2007) Infectivity of blood components with low hepatitis B virus DNA levels identified in a lookback program. Transfusion 47: 1197-1205.

17. Gerlich WH, Wagner FF, Chudy M, Harritshoj LH, Lattermann A, et al. (2007) HBsAg non-reactive HBV infection in blood donors: transmission and pathogenicity. J Med Virol 79: S32-36.

18. Hennig H, Puchta I, Luhm J, Schlenke P, Goerg S, et al. (2002) Frequency and load of hepatitis B virus DNA in first-time blood donors with antibodies to hepatitis B core antigen. Blood 100: 2637-2641.

19. Allain JP, Hewitt PE, Tedder RS, Williamson LM (1999) Evidence that anti-HBc but not HBV DNA testing may prevent some HBV transmission by transfusion. Br J Haematol 107: 186-195.

20. Comanor L, Holland P (2006) Hepatitis B virus blood screening: unfinished agendas. Vox Sang 91: 1-12.

21. Allain JP (2004) Occult hepatitis B virus infection: implications in transfusion. Vox Sang 86: 83-91.

22. Jafarzadeh A, Arababadi MK, Pourazar MMA (2008) Occult hepatitis B virus infection among blood donors with antibodies to hepatitis B core antigen. Acta Medica Iranica 46: 27-32.

23. Kleinman SH, Kuhns MC, Todd DS, Glynn SA, McNamara A, et al. (2003) Frequency of HBV DNA detection in US blood donors testing positive for the presence of anti-HBc: implications for transfusion transmission and donor screening. Transfusion 43: 696-704.

24. Nandi J, Banerjee K (1992) Detection of hepatitis B virus DNA in donor blood by the polymerase chain reaction. Natl Med J India 5: 5-7.

25. Kim SM, Lee KS, Park CJ, Lee JY, Kim KH, et al. (2007) Prevalence of occult HBV infection among subjects with normal serum ALT levels in Korea. J Infect 54: 185-191.

26. Almeida Neto C, Strauss E, Sabino EC, Sucupira MC, Chamone DA (2001) Significance of isolated hepatitis B core antibody in blood donors from São Paulo. Rev Inst Med Trop Sao Paulo 43: 203-208.

27. Ren F, Li H, Zhao H (1998) [Studies on hepatitis B virus infection in blood donors with positive anti-HBc and negative HBsAg]. Zhonghua Yu Fang Yi Xue Za Zhi 32: 7-9.

28. Sato S, Ohhashi W, Ihara H, Sakaya S, Kato T, et al. (2001) Comparison of the sensitivity of NAT using pooled donor samples for HBV and that of a serologic HBsAg assay. Transfusion 41: 1107-1113.

29. Bernvil SS, Andrews V, Kuhns MC, McNamara AL (1997) Hepatitis B core antigen antibody as an indicator of a low grade carrier state for hepatitis B virus in a Saudi Arabian blood donor population. Transfus Sci 18: 49-53. 
Citation: Abdelrazik AM, Abdelaziz HM (2015) The Role of Hepatitis B Core Antibody Testing in Improving Blood Safety in Resource-Limited Countries Study on Voluntary Blood Donors Fayoum, Egypt. J Blood Disord Transfus 6: 315. doi:10.4172/2155-9864.1000315

Page 4 of 4

30. Zahn A, Li C, Danso K, Candotti D, Owusu-Ofori S, et al. (2008) Molecular characterization of occult hepatitis B virus in genotype Einfected subjects. J Gen Virol 89: 409-418.

31. Kwok S, Higuchi R (1989) Avoiding false positives with PCR. Nature 339: 237-238.
32. Mosley JW, Stevens CE, Aach RD, Hollinger FB, Mimms LT, et al. (1995) Donor screening for antibody to hepatitis B core antigen and hepatitis B virus infection in transfusion recipients. Transfusion 35: 5-12.

33. Grob P, Jilg W, Bornhak H, Gerken G, Gerlich W, et al. (2000) Serological pattern "anti-HBc alone": report on a workshop. J Med Virol 62: 450-455. 